\title{
Enhancement of the Mechanism of Economic Regulation of Environment Protection and Nature Management in the Republic of Kazakhstan Based on the Use of Foreign Experience
}

\author{
Samat Smoilov ${ }^{1}$ \\ ${ }^{1}$ the Faculty of Law, the Department of Environmental and Business Law, L.N. Gumilyov National University, \\ Astana, the Republic of Kazakhstan \\ Correspondence: Samat Smoilov, the Faculty of Law, the Department of Environmental and Business Law, L. N. \\ Gumilyov National University, 2 Mirzoyana st., 010000, Astana, the Republic of Kazakhstan
}

Received: December 20, 2014

doi:10.5539/res.v7n3p80
Accepted: December 30, 2014 Online Published: February 25, 2015

URL: http://dx.doi.org/10.5539/res.v7n3p80

\begin{abstract}
The paper is concerned with comprehensive research of academic and application problems of legal groundwork for the mechanism of economic regulation of environment protection and nature management in the Republic of Kazakhstan. The paper deals with theoretic and methodological ideas of the radical change of the mechanism of economic regulation of environment protection and nature management under the conditions of the Republic of Kazakhstan shift to green economy. The work reveals basic definitions and categories, principles and structure elements of the mechanism of economic regulation of environment protection and nature management, the genesis of establishing and basic tendencies of legal regulation of the economic mechanism of environment protection and nature management are represented, the analysis of modern legislation part that regulates economic methods of environment protection and nature management is carried out, the issues of its legal groundwork efficiency upgrading are studied. As a result of researches theoretic principles and recommendation for the Republic of Kazakhstan's existing legislation and application practice improvement are stated.
\end{abstract}

Keywords: green economy, environmental protection, natural resource use, environmental safety, environmental damage, environmental audit, environmental monitoring, desertification, erosion, anthropogenic factors

\section{Introduction}

Environment protection economic regulation issues in the Republic of Kazakhstan are topical more than ever, which is associated with the proclamation of the Republic of Kazakhstan shift to green economy that was made in 2013. Green economy is defined as an economy of high living standards, careful and rational use of natural resources for the sake of current and future generations and in accordance with assumed international ecological commitments, including Rio Declaration on Environment and Development and Agenda 21, Johannesburg plan and Millennium Declaration (Davidyuk, 2008). In order to bring this shift about it's necessary to take stringent measures for environmental quality preservation even today. Shift to green economy is attributable to a number of factors. First of all, major economic sectors demonstrate ineffective resource management. "According to experts' estimates it leads to loss of profits in the amount of 4-8 billion US dollars per year, it may make up to 14 billion US dollars by 2030" (National mitigation banking association http://www.mitigationbanking.org/).

Secondly, there is degeneration of land quality due to natural processes of desertification, erosion, and due to anthropogenous factor (contamination, pollution, irrational use). Thirdly, there's a problem of rational use and water conservation in the Republic of Kazakhstan. The chosen theme is on the fringe of economics and legal science, for that reason a number of basic studies were carried out by academics economists.

Thus, such authors as Kosyakova (2007), Soltanbekova (2009), Chkhutiashvili (2012), and many others handled the issues of environment protection economic regulation. Theoretical issues of environmental economics are presented with the works of Bobylyova (2008), Girusova (1998), Hodzhaeva (2008) and others.

Though thesis researches are represented by academics economists, they give coverage to only one element of the financial regulation of environment protection. Thus, the following theses were defended: "Ecological taxes as an instrument of environmental mechanism: EU experience and prospects for Russia" (Lutkovskaya, 2008), 
"Budget mechanism rational use of natural resources and environment protection" (Toguzova, 2007), "Environmental protection measures regulation by means of taxes" (Freddy, 2002).

Some papers were concerned with economic mechanism development at production facilities (Davidyuk, 2008).

T. V. Burmistrova's "Economic regulation of environmental safety of Russia" thesis work is of complex nature (Burmistrova, 2000).

In the Republic of Kazakhstan complex monographic research was carried out by Soltanbekova B. E. on a topic "Environment protection in the Republic of Kazakhstan" (Soltanbekova, 2009).

Individual questions of legal groundwork for the mechanism of economic regulation of environment protection and nature management were explored in the works of Russian academic lawyers in the field of environmental, financial, administrative, and other branches of law, such as Dubovik (2005), Pozdnyakova (1999), Volkov (1999) and others, who touched upon the subject to a greater or lesser degree.

Thus, for example, individual questions of environmental financing were studied in the works of Morozova E. V. "Nature management and environment protection cost classification" (Morozova, 2007), Papenov K. V. "Economics and nature management" (Papenov, 1997), Grishin N. N. "Legal problems of public participation in Environmental Impact Assessment" (Grishin, 2000) and others.

The prime target of the work is integrated study of issues relating to the legal groundwork for the mechanism of economic regulation of environment protection and nature management by means of analysis of corresponding regulations and enforcement of the government in the field of exercise of environmental function, interaction of state agencies with designated authorities in the area of environmental protection:

In this regard the following tasks are set:

- To develop the definition of the mechanism of economic regulation of environment protection and nature management;

- To study background of Kazakhstan's experience of economic regulation in the area of environmental protection, summarize its positive and negative moments;

- To define the place of regulations on the mechanism of economic regulation of environment protection and nature management in the legal system;

- To identify legal mechanics enhancement issues regarding payments for environmental emission;

- To analyze source of funds inflow for environmental uses and procedure for their expenditure.

This problem requires in-depth and comprehensive analysis, which is associated with the necessity for theoretical developments and development of proposals and recommendations to elaborate most effective fiscal policy in the area, optimum economic mechanism of environment protection and nature management.

There is inconsistency of regulatory acts in this field, contradictions, inconsistency with the Constitution of the Republic of Kazakhstan; many regulations reflect lobbied interests of individual population groups; not all regulatory acts have social dimension regarding environmental law protection and legal interests of private and legal persons.

The existing mechanism of economic regulation of environmental protection and nature management is of fragmentary nature, consists of separate and not always interrelated components.

To make this mechanism functioning successful it's necessary to study main causes of its inefficiency, develop recommendations and proposals to create optimal system for legal groundwork for all components of this mechanism.

\section{Materials and Methods}

1) The operations of production facilities of the Republic of Kazakhstan from the perspective of environment protection can be assessed as harmful, however society has to keep balance between economy and environment protection. The question is the correlation of these two components of sound social and economic development. So far priority is given to economic concern. However Kazakhstan's proclamation of entry into the transition period to green economy may gradually change the situation.

2) Economic rates and statistical data do not present all ecological indicators. Thus, such protection lines as land conservation, water conservation, and atmosphere air conservation are distinguished, but wildlife protection, plant world conservation, and mineral wealth conservation are scarcely represented. It's necessary to introduce such indicators in order to reveal the broader picture of environment status. 
3) It's recommended to include into main forms of financial statements individual articles for environmental expenditures.

4) It's necessary to develop internal ecological standards of enterprises, which will be focused on ecological activity documentation, staff environmental training, internal environment audit, environmental monitoring, etc.

5) It's necessary to develop the system of incentives for effective ecotechnology adoption.

Scientific principles and research methods are used, which are based on requirements for objective and comprehensive analysis of processes and phenomena of social development, expenditure financing system operation for environmental protection and its legal basis.

The following methods were used in the study: Systematic approach; structural, functional; historic law; logic; statistical examination; comparative legal analysis; forecasting.

When studying the problems of environment protection economic mechanism implementation the method of functional approach was applied. Particularly two groups of methods were used-positive motivation methods and negative motivation methods.

Positive motivation methods are measures, which can get natural resources' users interested, incentives of natural resources' users who implement a policy of environmental conservation.

The following can be referred to this group: Environmental measures financing, exemption from payments into the treasury, concessional lending, bonus payment based on the results of ecological activity, retaining at enterprise's disposal and its assignment into economic incentives funds of share of profits from the sales of products made of production waste.

The Environmental Code of the Republic of Kazakhstan includes only environmental measures financing and material incentive of environment protection of the enumerated methods. Moreover, financing environmental measures carried out not of natural resources' users' own funds can be considered as positive method, and material incentive of environment protection will belong to positive methods if it brings property income and other profits for users of nature.

Negative motivation methods are measures, which are intended to natural resources' users' behaviour regulation in the interest of environmental conservation and rational use of natural resources by means of property deprivation. They include payment for environmental emission; payment for the use of certain types of natural resources; penalties, damages recovery.

The method of observation was applied, particularly, when studying enterprises' environmental safety state. For example when analyzing the volume of gross output of agricultural, forestry, and fisheries products in Kazakhstan in 2011 when it was 5\% of GDP, mining industry products-18.2\%; in 2012 the volume of gross output of agricultural, forestry, and fisheries products in Kazakhstan made up $4.3 \%$ of GDP, mining industry products- $17.5 \%$; and in 2013 the volume of gross output of agricultural, forestry, and fisheries products in Kazakhstan made up $4.5 \%$ of GDP, mining industry products- $16.5 \%$.

Statistical approach was applied when analyzing information regarding ecological situation status, environmental protection financing (emission, contamination, environmental costs). For example when analyzing environmental costs in the Republic of Kazakhstan there was data that in 2011 environmental costs for enterprises and organizations had made up 185.6 billion tenge.

Within the cost structure $28.8 \%$ fall at air and climate protection, $25.9 \%$-at wastes treatment management, $22.5 \%$ - at water source protection against sewage pollution, $17.9 \%$ - at protection and restoration of soils, ground waters and surface sources.

The method of comparative legal analysis was used. For example, environmental costs made up: In $2011-0.67 \%$; in $2012-0.64 \%$; and in $2013-0.64 \%$ of GDP.

\section{Results}

Regarding methods of economical regulation based on negative motivation we can also perform number of improvements.

First, in the Republic of Kazakhstan the reparation of ecological damage is mainly performed in monetary terms, although in the article 322, clause 4 of Ecological Code of the Republic of Kazakhstan there is a rule, in accordance with which the damage can be compensated in natural form by means of charging respondent with obligation on environmental restoration with consent of Parties and under the court decision.

The natural forms of compensation of damages include the measures on restoration of environment up to the 
state that was attached to it by the moment of causing of damage, provision of equivalent natural resource instead of destroyed or damaged one. The compensation of damage in natural form is performed by means of making Contract and/or Agreement regulating the order, conditions, terms and volumes of compensation.

We suppose that it is time to turn from the practice of compensation of ecological damage in monetary terms to the practice of direct restoration of environment as it is performed abroad. Particularly, it is the USA, where monetary form was substituted with "natural" form of damage compensation.

For assessment of ecological damage in the USA in 1990s there was an approach of conversion of loss of ecological system value to amounts of money (transportation and travel expenditures, hedonic evaluation, subjective evaluation, modeling of choice) that should be recovered from eco-breaker and used for restoration of damaged ecosystems (value-to-costs equivalency). The difficulty of such non-market assessment of damage has lead in the end of 1990s to transition to determination of equivalence between services of damaged ecosystems and services of restored or recreated ecosystems (service-to-service equivalency) for a man (fishery, hunt, tourism, bird-watching, prevention of floods or inflows, storms, recreation) and for performance of natural functions (inhabitation of animals and birds, reproduction of biologic species, biodiversity and genetic resources, food chains, biological cycles, etc.). At first such a method was related to analysis of equivalence of damaged and restored (recreated) inhabitations. Sometimes the approach was called "resource-to-resource equivalency" (Broughton \& Edward, 2005).

The restoration of damaged ecosystems was conducted in the units of inhabitation, not in the units of money, i.e. without reference to expenditures connected with restoration. For example, a sunken ship damages sea grass or ecosystem of coral reef. The time and place of disruption are known and well-marked. On the basis of scientific data we can evaluate time and surface necessary for natural or anthropogenic restoration of ecosystem and expressed in wasted hectare-years.

The task is the restoration of lost ecosystem as the compensation for inflicted ecological damage. At such an approach the environment is considered as economical asset providing the stream of services and there is no need for assessment of economical damage due to wastage of natural resources - we can at once speak about restoration of ecosystem with use of equal measurement units for services (lost and restored). Problems occur, if ecosystem services are reproduced in other place and other volume. The challenge was the pollutant, not American tax payer, to invest into restoration of damaged (polluted, physically destroyed) ecosystems.

Secondly, even in case of use of administrative instrument of influence on users of natural resources we can apply economical motivation. Thus, in the USA the amount of administrative ecological fines is estimated by two criteria: 1) the severity of breach of ecological standards, and 2) the size of benefit taken by eco-breaker as a result of non-compliance with ecological legislation. At the same time, if eco-breaker adheres to all or part of 9 conditions established by environmental authorities, the following advantages are applied: The payments on the first criterion are not collected or reduced by $75 \%$, the criminal proceedings and claims for presenting reports of audit are excluded, and withdrawal of amount of delivered benefit is left to the discretion of environmental body. Among 9 conditions there are: Conduction of systematic verifications of compliance with ecological legislation with help of ecological audit, independent detection of violations and urgent notification of environmental authorities within the period of 21 days, liquidation of violation and its consequences within 60 days from the date of detection, carrying out of measures to eliminate the renewal of violation (Shrivastava, 1987).

It is necessary to perform transition from the first type of economical mechanism to the second one aimed at development of ecologically harmless productions and types of activities. In the mechanism the role played by market instruments is quite big. The accepted in Kazakhstan Concept of transition to "green" economy basically implies implementation of such a mechanism as it makes provisions for decrease of energy intensity of production, development of alternative energetics, so-called social responsibility of government, business societies and civil society for every ecologically significant decision, investments into more effective and innovative ecological technologies.

One of such market instruments is ecological enterprising that is being considered by us as a kind of financial instrument for provision of ecological safety for it is initiative activity on production of goods, execution of works and rendering services intended primarily at conservation and restoration of environmental and protection of natural resources.

The ecological enterprising can develop in the direction of: Treatment of production and consumption wastes; waste recovery; use of wastes as alternative fuel; ecological tourism in the Republic of Kazakhstan, etc.

In particular, the most prospective and low-cost direction is ecological tourism. 
Ecological tourism similar to the whole tourist branch has three positive effects on economy of state:

- The economy of state is saturated with financial streams of subjects of foreign countries, tourism has positive impact on such economic indicators as balance of payments and overall export;

- Promote the employment of indigenous population, development of folk crafts. According to valuations of WTO and World Tourism and Travel Council for every work position created in the tourism industry there are from 5 to 9 work positions appeared in other branches of industry. Tourism has direct or indirect effect on development of 32 branches of economy;

- The development of tourism (even of ecological one) involves development of state infrastructure that promotes creation of new working positions, relevance of necessary production, construction materials, etc.

Thus, the industry of tourism possesses stronger multiplier effect than the majority of other economic sectors.

Another one direction to be stimulated is alternative energetics. Kazakhstan has significant potential of renewable energy - primarily in the form of hydraulic, wind and solar power. The potential is enough for provision of significant part of requirement of Kazakhstan of energy resources (MacKenzie, 2002).

The government should encourage the implementation in Kazakhstan of resource-saving and ecologically clean technologies. Among them there are, for example, biogas technologies preventing surface water reservoirs from pollution with nitrogen compounds. They can be used in peasant farms, for instance, by means of construction of biogas units.

We should also adopt the experience of Turkey in construction of "smart houses" equipped with solar cell batteries. The solar energy can be used for heating of water at small objects of production, which will help to refuse from combustion of organic fuel. In such a manner, we solve the task of provision of stable stand-alone power generation due to complex solar station.

The solar energy can also be used for getting distillate of drinking water with help of solar distillers and hot water for domestic needs of local population with help of solar water heaters.

The experience of use of renewable sources of energy allows detecting number of disadvantages. Among them there are: Insufficient education of potential consumers, low efficiency of construction of correspondent stations, lack of information about renewable sources of energy in Kazakhstan, absence of experience of using new technologies in Kazakhstan, cautious attitude of farmers and peasants towards new technologies, high cost of hi-tech automated biogas technologies being beyond the reach of the majority of citizens, absence of promoting policy of government, lack of financing of scientific research and engineering developments.

The specified problems should be solved with help of environmental enlightenment and education.

Another one problem to solve is the task of preservation of traditional principle of residual financing of affairs on environmental protection. Thus, there is a need of transition from residual principle of financing to "sufficient" principle, i.e.- when in government budget there is a separate line for "Environmental protection". At the present time in republic and local budgets the expenses for "environmental protection" are equated with expenses for "agro-industrial complex, water, forest, fishing industries, specially protected natural sites, land relations". This leads to mixture of expenses for listed needs and makes it seem that more money is allocated to protection of nature, than it is in actual fact (Wiche, 1990).

To solve the problem there is a need of advancing growth of budgetary provisions for environmental protection within the whole structure of national budget. We have already mentioned that the government had, unfortunately, removed itself from financing of ecological problems and holds the position of "supervisor" over users of natural resources, not of leader and organizer; and that it had stopped to be philanthropist and sponsor. However the world practice shows that the relation between governmental and local sources of formation of nation-wide expenditures expresses the dominance of governmental expenses, which increase faster than local ones.

And if it is difficult to solve the problem on the present stage of development of Kazakhstan, there is a necessity of involving the mechanism of public-private partnership, especially as in Kazakhstan so-called SEC (social and entrepreneurial corporations) have already existed.

The creation of SEC will promote increase of competitiveness of regions by means of implementation of mechanisms of cluster development, self-organization and mobilization of internal resources.

Thus, the participation of social and entrepreneurial corporations in ecological projects should be obligatory. 
The problem of mixture of notions of "ecological payments" and "ecological taxes" should also be solved. We suppose that payments for emissions into environment and payments for use of separate types of natural resources should carry a load of payments indeed, not of taxes, and they should not be a fiscal tool. Besides, we should lay on impositions for ecologically "dirty" products - engine oil, petrol, transport facilities polluting environment, consumer packaged goods containing injurious for man and environment substances, etc.

To increase the motivation of users of natural resources we should establish concessional taxation.

Another one important affair is active use of opportunities of environmental insurance. We should provide public support of insurance companies performing ecological insurance.

We also suggest the creation of government fund of ecological insurance that will perform reinsuring in case of environmental emergencies.

The solution of ecological problems in Kazakhstan can also be performed by means of establishment of customs taxes for production imported to the Republic of Kazakhstan from abroad and non-complied with ecological requirements and causing ecological damage.

In addition, we should "revive" off-budget environmental funds, the funds of which can form owing to voluntary contributions of population, material assistance of foreign investors, due to accumulation of funds from administrative fines, sums of ecological damage compensation, etc.

The monetary assets from above-listed sources should be spent only on ecological affairs for those very enterprises transferred funds for their restoration. For the purpose of avoidance of inappropriate use of money, apart from their tighten control, we should implement the system of independent supervisors by using means of public ecological control.

The compensation of ecological damage should be performed in two ways. The priority way should cover the natural form of compensation. The second way is to be presented with money compensation steered to special "ecological" accounts.

\section{Discussion}

One of the main problems is the problem of uneven correlation between the methods of positive motivation and the methods of negative motivation related to the methods of economical motivation. The practice of financial regulation of environmental protection and exploitation of natural resources in the Republic of Kazakhstan demonstrates that its methods of economical regulation are mainly presented with ones referred to the methods of negative motivation. That is why our suggestion is addition of mechanism of economic regulation of environmental protection and natural management with methods of economical regulation based on positive motivation.

For this purpose we should utilize the positive experience of foreign states regarding this matter.

Thus, in the USA one of the methods of positive economical motivation is the system of special bank crediting. There is, for example, National Mitigation Banking Association that has been acting since 1998 and supported by "eco-bankers" - the persons, who purchase the sites of desolated wetlands, restore them, provide their long-term functioning and issue (sell) eco-credits to those willing to start own business activity on the territory of other wetland site (and in such a manner- to damage its eco-system). Having bought such a credit, an executive manager presents it to local environmental body for getting permit for his business activities. Notably that in such a case he should not conduct ecological recovery works (Perelet, 2009).

We suppose that such experience can be implemented in the Republic of Kazakhstan and that on the initial stage government should lend assistance in creation of credit organizations, the main purpose of which will be accommodation of loans for ecological affairs.

Another one decision is introduction of bank interest rating depending on ecological stability of users of natural resources, as it is suggested by Shimova (2005).

The example of efficiency of such rating being the mean of displacement of ecologically danger production is an emergency occasion at the chemical plant of "Union Carbide Corporation (UCC)" company (India), in consequence of which all the enterprises of the corporation in different parts of the worlds were switched by banks to much higher percent as ecologically unreliable that had practically demolished the firm.

In 1970 the government of India started implementation of policy on attraction of foreign investments to local industry. Union Carbide Corporation (UCC) gained admittance for constructing in Bhopal the plant for production of pesticides for needs of farming sector. The plant was built by affiliated company of Union Carbide 
India Limited (UCIL). Initially it was planned that for production of pesticides the plant was to import some part of chemicals produced by UCC. However, trying to compete with other chemical factories, the plant in Bhopal had been switched to more complex and hazardous production. The bad harvests in India in 1980s had reduced the demand for production of the plant and it was prepared for sale in July, 1984. However, no buyer was found and the work of the plant proceeded with equipment that by that time had not met safety standards (EPA Audit Policy, 2000).

The plant of Union Carbide produced by that time the insecticide called Sevin (carbaryl, 1-naphthyl-N-methyl carbamate). This pesticide is produced by reaction of methylisocyanate with $\alpha$-naphthol in the environment of tetrachloromethane. Methylisocyanate (hereinafter referred to as MIC) was stored at the plant in three partially imbedded into ground containers, each of which could contain about 60000 liters of liquid.

The direct cause of the tragedy was emergency emission of vapors of methylisocyanate that had heated over the boiling temperature $\left(39^{\circ} \mathrm{C}\right)$, what had led to pressure increase and explosion of emergency valve. As a result within the period from 0:30 to 2:00 on December 3, 1984 about $42 \mathrm{t}$. of poisonous vapors was discharged into the atmosphere. The methylisocyanate cloud covered nearby slum quarters and railway station located in $2 \mathrm{~km}$. from the enterprise. The big amount of victims is explained with high density of population, its untimely informing, lack of medical personnel and unfavorable weather conditions - the cloud of heavy vapors was spread with wind.

According to various data, the total amount of injured persons had made 150-600 thousand men, whereupon 3 800 men died at once (mainly, in poor colony of slum quarters close to UCC plant) and 15000 more died in subsequent years due to the impact chemicals on organism. These numbers make the Bhopal tragedy the biggest technogenic catastrophe in the world.

Union Carbide responsible for the tragedy in 1987 within the frameworks of out-of-court settlement paid 470 mln. dollars to the victims of the emergency in exchange for refusal from further legal claims. On June 7, 2010 Indian court accounted seven former leaders of Indian subsidiary office of Union Carbide guilty of negligence resulted in loss of life. The convicted persons were sentenced to two years of imprisonment and fine at a rate of 100 thousand rupees (approximately $\$ 2100$ ).

After the tragedy in India the "Union Carbide Corporation (UCC)" lost its business reputation, which led to increase of interest on bank loan for all the enterprises of the present corporation.

The tax legislation of the Republic of Kazakhstan should be also added with amendments regarding depreciation payments by the example of such states as Japan, USA, Federal Republic of Germany, where similar system has been used for a long time. The article 120 of the Code of the Republic of Kazakhstan "About taxes and other obligatory payments to budget" (the Tax Code) says that the limit for amortization of machines and equipment, except for machines and equipment used for oil and gas production, as well as of computers and information processing equipment makes no more than $25 \%$. This relates also to treatment facilities. However, according to the experience of foreign states, in respect of small and medium-sized enterprises, which need assistance to a greater degree, the depreciation of assets for environmental protection within the first year of operation can make up to $50 \%$ when performing environmental affairs.

Thus, to perform the "turn" to the methods of positive motivation as opposed to the methods of negative motivation the whole specter of positive motivators should be used in the mechanism of economic regulation of environmental protection.

\section{Acknowledgments}

During preparation of the article big assistance was lent by the scientists specialized on the problems of environmental protection and in particular-by S. J. D. professors of L. N. Gumilyov National University Mukasheva Anara Abaykhanovna and Kosanov Zhumash Khazhimbaevich.

\section{References}

Bobylyova, S. N. (2008). Environmental economics: Textbook (pp. 147-156). Moscow: Infra-M.

Broughton, E. (2005). The Bhopal disaster and its aftermath: A review. Environmental Health: A Global Access Science Source, 4, 6.

Burmistrova, T. V. (2000). Economic regulation of environmental safety of Russia (pp. 75-84). Ph.D. in Economics. Moscow.

Davidyuk, Y. V. (2008). The Mechanism of Eco-economic Regulation of the operation of industrial production environmental management subjects (pp. 36-52). D. in Economics. Rovno. 
Davidyuk, Y. V. (2008). The Mechanism of Eco-economic Regulation of the operation of industrial production environmental management subjects (pp. 25-32). Ph.D. in Economics. Rovno.

Dubovik, O. L. (2005). Environmental law (pp. 74-92). Moscow: Eksmo.

Girusova, E. V. (1998). Ecology and environmental economics: Textbook for universities (pp. 135-148). Moscow: Zakon I Pravo, UNITY.

Grishin, N. N. (2000). Legal problems of public participation in Environmental Impact Assessment (pp. 85-96). of Candidate of Legal Sciences. Moscow.

Hodzhaeva, A. S. (2008). Environmental economics: Text-book (pp. 124-138). Moscow: Infra-M.

Kosyakova, I. V. (2007). Methological Foundations of the formation of mechanism of economic groundwork for environmental safety of production facilities operations (pp. 39-56). Doctor of Economics. Samara.

Lutkovskaya, S. Y. (2008). Ecological taxes as an instrument of environmental mechanism: EU experience and prospects for Russia (pp. 98-112). Ph.D. in Economics. St. Petersburg.

MacKenzie, D. (2002). Fresh evidence on Bhopal disaster. New Scientist, 19(1), 16.

Maedza, F. (2002). Environmental protection measures regulation by means of taxes (pp. 89-96). Ph.D. in Economics. St. Petersburg.

Morozova, E. V. (Unknown). Cost classification for nature management and environment protection (pp. 45-51). Retrieved from http://www.rae.ru/zk/arj/2007/04/Morozova.pdf

National mitigation banking association (Unknown). http://www.mitigationbanking.org/17-21

Papenov, K. B. (1997). Economy and nature management. Moscow.

Pozdnyakova, T. A. (1999). Financial regulation of social and economic processes (pp. 112-114). Doctor of Economics. St. Petersburg.

Shimovoy, O. S. (2005). Ecology and environmental economics: Part 2. In Course of lectures (2nd ed., pp. 57-63). Minsk: Academy of management under the President of the Republic of Belarus.

Shrivastava, P. B. (1987). Anatomy of a Crisis (p. 184). Cambridge, MA, Ballinger Publishing.

Soltanbekova, B. E. (2009). Enhancement of the organizational and economic mechanism of environment protection in the Republic of Kazakhstan (pp. 17-19). Ph.D. in Economics. Karaganda.

Soltanbekova, B. E. (2009). Enhancement of the organizational and economic mechanism of environment protection in the Republic of Kazakhstan (pp. 15-24). Ph.D. in Economics. Karaganda.

Toguzova, I. Z. (2007). Budget mechanism rational use of natural resources and environment protection (pp. 56-74). Candidate of Economic and Legal Sciences. Vladikavkaz.

US EPA Audit Policy. (2000). Incentives for Self-Policing: Discovery, Disclosure, Correction and Prevention of $\begin{array}{llll}\text { Violations (pp. } & \text { 45-57). } & \text { Retrieved }\end{array}$ http://www.epa.gov/compliance/resources/policies/incentives/auditing/auditpolicy51100.pdf

Volkov, A. A. (1999). Financial mechanism of environment protection, Finansy, 3, 56-58.

Wiche, Z. (1990). Rechnet sich Umweltshulz. Z. Wiche, N. Lanz (1990). Umweltmagazin, 8, 24-26.

\section{Copyrights}

Copyright for this article is retained by the author(s), with first publication rights granted to the journal. This is an open-access article distributed under the terms and conditions of the Creative Commons Attribution license (http://creativecommons.org/licenses/by/3.0/). 